\begin{tabular}{|l|l|r|}
\hline & Al Fitrah & Mendidik Anak Usia Dini Dengan \\
Journal Of Early Childhood Islamic Education & Berlandaskan Pemikiran Tokoh Islam \\
Il-Ghazali \\
ISSN : 2599-2287 E-ISSN : 2622-335X \\
Vol.2 No.2 Januari 2019
\end{tabular}

\title{
MENDIDIK ANAK USIA DINI DENGAN BERLANDASKAN PEMIKIRAN TOKOH ISLAM AL-GHAZALI
}

\begin{abstract}
Abstrak
Al-Ghazali merupakan salah satu tokoh Muslim yang pemikirannya sangat luas dan mendalam dalam berbagai hal diantaranya dalam masalah pendidikan. Konsep Pendidikan anak yang diusung oleh Al-Ghazali berpijak pada Al-Qur'an dan As-Sunnah sebagai dasar pendidikan anak. Anak yang lahir menurut al-ghazali suci dan bersih orang tua lah yang akan bertanggung jawab mendidiknya. Terdapat dua pendidikan anak tahapan janin dan tahapan kanak-kanak (thifl). Pokok pemikiran al-ghazali dalam mendidik anak : Pentingnya peran orang tua dan pendidikan akhlak bagi anak usia dini, Seimbangkan antara perintah dengan keteladanan. Gunakan metode pengajaran yang sesuai dengan minat dan bakatnya (kecerdasan jamak) Berikan waktu anak untuk bermain Berikan kegiatan positif di waktu luangnya Reward and Punishment. Pendidikan yang dirumuskan Al-Ghazali mencakup banyak aspek yaitu pendidikan keimanan, pendidikan akhlak, pendidikan 'aqliyah, pendidikan sosial dan pendidikan jasmani. Mengenai metode Al-Ghazali menganjurkan penggunaan metode yang bervariasi yang harus disesuaikan dengan tahap perkembangan akal fikiran anak. Seperti hafalan, pemahaman, pembiasaan, latihan dan lain sebagainya.
\end{abstract}

\section{Kata Kunci : Mendidik Anak Usia Dini, Pemikiran, Al- Ghazali}

\author{
Miya Rahmawati \\ Mrmiya73@gmail.com \\ UIN Sunan Kalijaga
}

\section{PENDAHULUAN}

Bersamaan dengan perputaran dunia, modernisasi dan pengembangan ilmu pengetahuan dari hari ke hari semakin berkembang, akhir-akhir ini kita melihat banyak generasi Islam yang sudah tidak mengenal para tokoh Islam yang sangat berpengaruh terhadap kemajuan dunia pendidikan. Mereka kadang meremehkan dengan mengatakan, "Di mana tokoh Islam". Hal ini terjadi karena mereka kurang mengenal terhadap beberapa tokoh Islam yang berhasil mencetak generasi yang tidak kalah hebat dengan tokoh pendidikan nonMuslim dalam mencetak generasi berakhlak alkarimah, disiplin, terhormat, serta bermanfaat untuk kepentingan agama, nusa, dan bangsa.

Seorang tokoh pemikir Islam yang tak kalah tersohornya di dunia Islam maupun Barat adalah Al-Ghazali. Ia merupakan salah satu tokoh Muslim yang 


\begin{tabular}{|l|l|r|}
\hline A1 Fitrah & $\begin{array}{r}\text { Mendidik Anak Usia Dini Dengan } \\
\text { Journal Of Early Childhood Islamic Education }\end{array}$ \\
ISSN $:$ 2599-2287 E-ISSN $:$ 2622-335X & Alandaskan Pemikiran Tokoh Islam \\
Vol.2 No.2 Januari 2019 & Miya Rahmawati \\
\hline
\end{tabular}

pemikirannya sangat luas dan mendalam dalam bidang tasawuf, ilmu kalam, falsafah, akhlak, fiqih dan berbagai bidang keilmuan, termasuk bidang pendidikan. Menurut Philip K. Hitti, sebagaimana dikutip oleh Nurcholish Madjid, Al-Ghazali digolongkan sebagai salah seorang yang paling menentukan jalannya sejarah Islam dan bangsa-bangsa Muslim. Bahkan, dalam bidang pemikiran dan peletakkan dasar ajaran-ajaran Islam, Al-Ghazali ditempatkan di urutan kedua setelah Rasulullah. Ia adalah seorang pemikir yang tidak saja mendalam, tapi juga sangat subur dan produktif dengan karyakaryanya. ${ }^{1}$

Al-Ghazali merupakan salah satu tokoh Muslim yang pemikirannya sangat luas dan mendalam dalam berbagai hal diantaranya dalam masalah pendidikan. Beliau adalah salah satu ulama yang amat berpengaruh dan diagungkan di dunia Islam yang diberi gelar hujjat al-Islam. al-Ghazali seorang pemikir yang tidak saja mendalam, tapi juga sangat subur dan produktif dengan karya-karyanya

\section{Riwayat Hidup Al-Ghazali}

\section{- Biografi Al-Ghazali}

Julukan Al-Ghazali diambil dari nama sebuah kata "Ghazabeh" di dekat kota Tus di wilayah khurasan yang merupakan kota

\footnotetext{
${ }^{1}$ Nurcholish Madjid, Islam Kemodernan dan Keindonesiaan, Bandung, Mizan, 1998,hlm.280
}

tempat kelahirannya. Nama lengkap AlGhazali ialah Abu Hamid Muhammad bin Muhammad bin Muhammad bin Ahmad Al-Ghazali, ia dilahirkan pada tahun 450 Hijriyah bertepatan dengan tahun 105 Miladdiyah. $^{2}$

Ayahnya adalah seorang muslim yang saleh, sekalipun ia seorang yang kurang berada dan hanya memiliki usaha bertenun wol, beliau termasuk orang yang tekun dalam mengikuti pengajian para ulama dan pencinta ilmu yang selalu berdoa agar putranya menjadi seorang ulama yang pandai memberi nasehat. Beliau meninggal saat Al-Ghazali dan saudaranya ahmad masih kecil sehingga beliau tidak menyaksikan ketika doanya terkabul. Sebelum meninggal beliau menitipkan anak-anaknya kepada seorang sufi, sahabatnya untuk dididik dan dibimbingnya dengan baik.

Al-Ghazali dan saudaranya ditinggali harta warisan untuk bekal hidup, tetapi harta itu habis. Karena sufi juga termasuk orangnya sederhana ia tidak mampu memberikan tambahan nafkah maka AlGhazali dan adiknya diserahkan ke sekolah yang menyediakan biaya hidup bagi muridnya.

${ }^{2}$ M. Bahri Ghazali, Konsep ilmu menurut Al-Ghazali, Yogyakarta 1991 Pedoman Ilmu Jaya. hlm. 23 


\begin{tabular}{|l|l|r|}
\hline & Al Fitrah & Mendidik Anak Usia Dini Dengan \\
Journal Of Early Childhood Islamic Education & Berlandaskan Pemikiran Tokoh Islam \\
Al-Ghazali \\
ISSN : 2599-2287 E-ISSN : 2622-335X \\
Vol.2 No.2 Januari 2019
\end{tabular}

Perjalanan hidup al-Ghazali dalam menuntut ilmu dan mencari jati diri sangat panjang dan berliku-liku. Perjalanan panjang tersebut pada akhirnya mengantarkannya menjadi seorang tokoh besar yang tidak saja dikagumi di dunia timur, tetapi dunia barat juga mengakui kehebatan dan kebesarannya. Berbagai karya tulis telah dihasilkannya dalam berbagai bidang; filsafat, logika dan tasawuf, termasuk di dalamnya tentang pendidikan. Tidak mengherankan jika ia digelari dengan Hujjatul Islam, al-Imam alJalil, Zainuddin dan lain sebagainya. Ia meninggal dunia pada tahun $505 \mathrm{H} / 1111 \mathrm{M}$ di usianya yang ke 55 tahun.

\section{- Karya-Karya Al-Ghazali}

Al-Ghazali adalah seorang ulama yang aktif dan produktif menghasilkan puluhan karya ilmiah dari berbagai bidang ilmu pengetahuan. Al-Ghazali telah meninggalkan tulisannya berupa buku dan karya ilmiah sebanyak 228 kitab yang terdiri dari beraneka ragam ilmu pengetahuan yang terkenal pada masanya. Di bawah ini hanya akan disebutkan beberapa warisan dari karya ilmiahnya yang paling besar pengaruhnya terhadap pemikiran umat islam, antara lain: Ihya'Ulum al-Din, berisikan kumpulan pokok-pokok agama dan akidah, ibadah, ahlak, dan kaidah-kaidah suluk. Al-Iqtisad fi al-I"etiqad, diuraikan didalamnya akidah menurut aliran al-Asy'ariah. Maqasid alFalasifah, berisikan ilmu mantiq, alam dan ketuhanan. Tahafut al-Falasifah, berisikan kritikan terhadap filosof. Al-Munqizd min al-Dhalal, dipaparkan di dalamnya seperangkat ilmu yang mewarnai zamanya dan berbagai aliran yang penting ilmu dan aliran-aliran tersebut dikajinya secara kritis , kemudian dijelaskan kelebihan dan kesalahan-kesalahanya. Mizan al-Amal, di dalamnya berisikan penjelasan tentang ahlak. $^{3}$

\section{Pemikiran Al-Ghazali tentang}

\section{Pendidikan anak}

Sistem pendidikan Al-Ghazali sangat dipengaruhi luasnya ilmu pengetahuan yang dikuasainya, sehingga dijuluki filosuf yang ahli tasawuf (Failasuf al-Mutasawwifin). Dua corak ilmu yang telah terpadu dalam dirinya itu kemudiaan turut mempengaruhi formulasi komponen-komponen dalam sistem pendidikannya.

Menurut Imam Al-Ghazali nilai pendidikan memiliki beberapa penekanan yang sangat besar terhadap pengembangan ilmu pendidikan tersebut, melalui peningkatan pendidikan yang di dukung melalui seorang pendidik dan juga peserta didik. Konsep pendidikan menurut Al-

\footnotetext{
${ }^{3}$ Sirajuddin Zar, Filsafat Islam:Filosof Dan Filsafatnya Depok :2012 Rajagrafindo Persada Halm 159
} 


\begin{tabular}{|l|l|r|}
\hline A1 Fitrah & $\begin{array}{r}\text { Mendidik Anak Usia Dini Dengan } \\
\text { Journal Of Early Childhood Islamic Education }\end{array}$ \\
ISSN $:$ 2599-2287 E-ISSN $:$ 2622-335X & Alandaskan Pemikiran Tokoh Islam \\
Vol.2 No.2 Januari 2019 & Miya Rahmawati \\
\hline
\end{tabular}

Ghazali berintikan pada pewarisan nilainilai budaya suatu masyarakat kepada setiap individu yang ada dalam agar kehidupan budaya dapat berjalan secara berkesinambungan. ${ }^{4}$ Ciri khas sistem alGhazali sebenarnya terletak pada pengajaran moral religius dengan tanpa mengabaikan urusan dunia. Al-Ghazali mengungkapkan, bahwa pendidikan sebagai suatu sistem yang terdiri dari beberapa komponen sebagai berikut :

\section{Anak Dalam Pandangan Al-Ghazali}

Membicarakan tentang pendidikan, maka tentu tidak terlepas dari membicarakan anak karena anak merupakan bagian dari pendidikan yakni sebagai subjek sekaligus sebagai objek dalam pendidikan. Anak terlahir dengan membawa berbagai potensi yang dimilikinya, dan potensi-potensi inilah yang menjadi tanggung jawab orang tua dan pendidik untuk mengenal dan mampu mengembangkan dari potensi itu. Perhatian Al-Ghazali terhadap pendidikan anak berhubungan erat dengan pandangannya terhadap anak, sehingga dalam karangannya Ihya' 'Ulum Ad-din mengungkapkan bahwa :

"Anak merupakan amanah bagi kedua orang tuanya, Hatinya yang suci seperti permata yang indah dan menawan serta bersih dari

\footnotetext{
${ }^{4}$ Muhammad Edi Kurnanto, "Pendidikan Dalam Pemikiran Al-Ghazali," Khatulistiwa 1, no. 2 (1 September 2011) https://doi.org/10.24260/khatulistiwa.v1i2.189.
}

segala ukiran dan gambar. Ia menerima semua yang diukirkan padanya dan condong pada sesuatu yang diarahkan padanya. Jika ia dibiasakan dan didik berbuat baik maka ia tumbuh dengan berbuat baik dan bahagia di dunia dan akhirat, orang tua dan para pendidiknya ikut serta mendapatkan pahalanya. Tapi jika ia dibiasakan berbuat kejelekan dan ia dicondongkan padanya maka ia akan celaka dan rusak, dan para pendidiknyapun akan mendapatkan dosanya". 5

Dengan demikian, pendidikan adalah mutlak, keberadaaanya adalah suatu keharusan dalam upaya mengembangkan potensinya agar tidak tercemar dan terkena polusi lingkungan yang kotor dan tidak bertanggung jawab. Tentunya pendidikan yang dimaksud adalah pendidikan yang mempunyai arah dan tujuan yang jelas, sehingga jelas pula bentuk dan model yang diinginkannya.

\section{Tahap -Tahap Perkembangan Anak}

\section{Menurut Al-Ghazali}

Menurut Al Ghazali, pendidikan anak usia dini dapat dikelompok besarkan menjadi dua tahapan, yaitu tahapan janin dan tahapan kanak-kanak (thifl) :

5 Sitti Riadil Janna, "KONSEP PENDIDIKAN ANAK DALAM PERSPEKTIF ALGHAZALI (Implikasinya dalam Pendidikan Agama Islam)," Al-Ta'dib 6, no. 2 (1 Juni 2013): 41-55, https://doi.org/10.31332/atdb.v6i2.304. 


\begin{tabular}{|l|l|r|}
\hline & Al Fitrah & Mendidik Anak Usia Dini Dengan \\
Journal Of Early Childhood Islamic Education & Berlandaskan Pemikiran Tokoh Islam \\
Il-Ghazali \\
ISSN : 2599-2287 E-ISSN : 2622-335X \\
Vol.2 No.2 Januari 2019
\end{tabular}

\section{- Tahapan janin.}

Ajaran Islam menyebutkan bahwa masa kehamilan/tahapan janin merupakan masa yang menentukan bagi kehidupan masa depan anak. Apa yang dirasakan anak ketika masih dalam kandungan digambarkan sebagai situasi yang akan dialami anak dalam kehidupan selanjutnya. Oleh karena itu, pada masa kehamilan orangtua disarankan untuk menjaga diri dari sifat dan sikap negatif serta memperbanyak kegiatan positif. Yaitu dengan cara memperbanyak ibadah dan terbiasa menyucikan diri sebelum melakukan pekerjaan sehari-hari. Kondisi suci yang diciptakan dalam lingkungan keluarga itu diyakini akan berpengaruh pada perkembangan janin yang dikandung oleh si ibu. Hubungan langsung antara orang tua dan anak memang belum berlangsung secara fisik, tetapi kondisi dan kegiatan orang tua diakui berpengaruh pada kehidupan janin dalam kandungan. ${ }^{6}$

Sebelum itu, Al Ghazali terlebih dahulu membahas masalah tentang proses pendidikan masa konsepsi yang terdapat dalam Adab Al Muasyarah (adab pergaulan suami istri). ${ }^{7}$ Dalam adab yang kesepuluh dari bab tersebut $\mathrm{Al}$ Ghazali menerangkan

\footnotetext{
${ }^{6}$ Abu Muhammad Iqbal, Konsep Pemikiran Al Ghazali Tentang Pendidikan, (Madiun: Jaya Star Nine, 2013), hlm. 50

${ }^{7}$ Al Ghazali, Ihya Ulumuddin, Jilid II, Alih bahasa H. Ismail Jakub, (Jakarta: CV. Faizan,
} tth.), hlm. 427 tentang tata cara bersetubuh yang benar menurut sunnah Rasul, diantaranya adalah membaca basmalah, surat Al Ikhlas, takbir, tauhid, tahlil, dan doa-doa lainnya.

Dari sini terlihat bahwa pendekatan psikologis pada masa ini mulai diterapkan dengan cara lebih mendekatkan diri kepada Allah Swt seperti memperbanyak amal shaleh, memperbanyak amal kemanusiaan, dan senantiasa berharap anak yang akan lahir kelak menjadi anak yang benar-benar shaleh. Penerapan doa kebaikan bagi anak ini tentu tidak hanya diucapkan saat hendak bersetebuh saja, melainkan harus dilakukan secara kontinyu/istiqomah.

Segera setelah istri diketahui positif mengandung, pendidikan anak sudah harus mulai aktif dilakukan melalui ibunya. Dari segi pertumbuhan dan kesejahteraan fisiknya, janin dalam kandungan dapat dijaga melalui pemenuhan makanan yang halal dan baik supaya kesehatan ibu lebih terjaga. Meskipun makanan yang halal tidak langsung diberikan kepada janin, tetapi hal itu justru mendasar karena makanan yang baik dan halal akan membentuk janin yang baik dan halal pula. Al Ghazali menegaskan bahwa jika anak terutama masa prenatal- diberikan asupan makanan yang haram maka darah, daging, atau pun segala sesuatu yang berkaitan dengan tubuhnya akan menjadi haram. Bila sudah begitu, akan selalu muncul keinginan 


\begin{tabular}{|l|l|r|}
\hline A1 Fitrah & $\begin{array}{r}\text { Mendidik Anak Usia Dini Dengan } \\
\text { Journal Of Early Childhood Islamic Education }\end{array}$ \\
ISSN $:$ 2599-2287 E-ISSN $:$ 2622-335X & Alandaskan Pemikiran Tokoh Islam \\
Vol.2 No.2 Januari 2019 & Miya Rahmawati \\
\hline
\end{tabular}

dalam dirinya untuk memakan, mencium, melihat, dan merasakan hal-hal yang haram, meskipun ia memiliki kesempatan untuk merasakan yang halal. Sementara dari segi

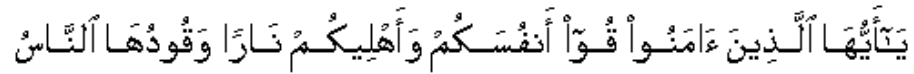

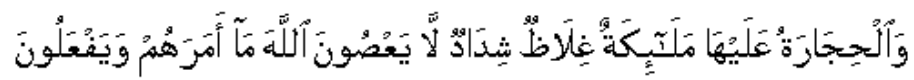
psikologisnya, janin tersebut dipelihara melalui pembinaan suasana rumah tangga yang sedemikian rupa sehingga ibu yang mengandungnya tetap merasakan ketentraman, dan kestabilan emosi. ${ }^{8}$

\section{- Tahapan kanak-kanak}

Keluarga merupakan lingkungan yang pertama kali akan mewarnai kehidupan anak setelah ia dilahirkan ke dunia ini. Masa kanak-kanak (thifl) merupakan masa/waktu yang amat penting dan paling kritis dalam kehidupan anak (usia prasekolah). Sebab pada masa tersebut apa yang ditanamkan dalam diri anak akan sangat membekas sehingga tidak mudah hilang atau berubah.

\section{Dasar-Dasar Pendidikan Anak}

Dasar atau sumber yang dijadikan pijakan pendidikan Al-Ghazali sama dengan dasar pendidikan Islam, yakni Al-Qur'an, AsSunnah dan dilengkapi oleh Atsaru AshShobahah. Dasar-dasar pendidikan anak yang menjadi pijakan Al-Ghazali dalam mrumuskan segala sesuatu yang berhubungan dengan pendidikan anak. Demikian dasardasar pendidikan anak adalah :

\section{Dasar Al-Quran}

${ }^{8}$ Ahmad Tafsir (ed.), Pendidikan Agama dalam Keluarga, (Bandung: PT. Remaja Rosdakarya, 2002), hlm. 35

Terjemah: "Hai orang-orang yang beriman, peliharalah dirimu dan keluargamu dari api neraka yang bahan bakarnya adalah manusia dan batu; penjaganya malaikat-malaikat yang kasar, yang keras yang tidak mendurhakai Allah terhadap apa yang diperintahkan-Nya kepada mereka dan selalu mengerjakan apa yang diperintahkan". (Surat At-Tamrin Ayat 6)

\section{Dasar As-Sunnah}

Seperti dalam hadis "Setiap manusia dilahirkan ibunya di atas fitrah. Kedua orang tuanya yang menjadikannya Yahudi, Nasrani, atau Majusi."

Dengan demikian menurut Al-Ghazali setiap anak memiliki fitrah dan kecenderungan kearah baik dan buruk Oleh karena itu peran pendidikan dalam hal ini orang tua dan guru sangat diperlukan untuk mengarahkannya pada perilaku baik. Selain itu dapat diketahui bahwa Islam tidak hanya mengakui faktor hereditas sebagai faktor yang mempengaruhi perkembangan tetapi juga faktor lingkungan. 


\begin{tabular}{|l|l|r|}
\hline & Al Fitrah & Mendidik Anak Usia Dini Dengan \\
Journal Of Early Childhood Islamic Education & Berlandaskan Pemikiran Tokoh Islam \\
Il-Ghazali \\
ISSN : 2599-2287 E-ISSN : 2622-335X \\
Vol.2 No.2 Januari 2019
\end{tabular}

\section{Tujuan Pendidikan Anak}

Tujuan pendidikan anak dalam pandangan Al-Ghazali tentu tidak berbeda dengan tujuan pendidikan secara umum yaitu untuk mendekatkan diri kepada Allah. AlGhazali mengatakan bahwa sungguh aku telah mengetahui bahwa sesungguhnya buah ilmu adalah kedekatan dengan Tuhan semesta alam. Jadi tujuan pendidikan anak adalah : Pengembangan jasmani dan rohani sebagai sumber kebahagiaan dunia, Taqararub ila allah sebagai sumber kebahagiaan akhirat. ${ }^{9}$

Terkait tujuan pendidikan Al-Ghazali mengatakan jika anak dibiasakan dan diajarkan berbuat baik maka ia akan memiliki kecenderungan untuk berbuat baik sampai ia dewasa atau bahkan sampai tua. Hal itu terjadi karena nilai-nilai kebaikan telah meresap dalam dirinya dan telah menjadi pola pikir, sikap dan perilakunya. Hal itu terjadi karena nilai-nilai kebaikan telah meresap dalam dirinya dan telah menjadi pola pikir, sikap dan perilakunya. "Baik" di sini tentu tidak terbatas pada aspek moral atau akhlak tapi juga aspek yang lain seperti sosial, spiritual bahkan juga motoriknya.

\section{Pokok Pikiran Al-Gazali Terhadap}

\section{Pendidikan Anak Usia Dini}

\footnotetext{
${ }^{9}$ Nurus Sa'adah, “Konsep pendidikan anak dalam perspektif Al-Ghazali: Analisis teori tahaptahap perkembangan jean piaget" (undergraduate, Universitas Islam Negeri Maulana Malik Ibrahim, 2008), http://etheses.uin-malang.ac.id/4282/.hlm.14
}

Ada beberapa pokok-pokok pikiran $\mathrm{Al}$ Ghazali yang berkaitan dengan masa kanakkanak ini, diantaranya : ${ }^{10}$

\section{a. Pentingnya peran orang tua dan pendidikan akhlak bagi anak usia dini}

Al Ghazali adalah seorang pemuka agama yang sufi. Karena itu pertama kali ia memandang penting membina dan mengisi hati anak kecil dengan melatih jiwanya untuk beribadah, bermakrifah kepada Allah dan mendekatkan diri, kepada-Nya. Dan semua itu tidak akan tercapai kecuali dengan menanamkan sendi-sendi agama yang benar di dalam dada anak kecil sejak masa pertumbuhannya.

Al Ghazali juga menasehatkan agar orang tua atau pendidik menjauhkan anak didiknya dari teman-teman yang berperilaku kurang baik sebagai jalan bagi pembinaan mental anak. Dinasehatkan juga agar orang tua tidak memanjakannya, memupuk dengan kenikmatan, mengundurkan semangat, malas, dan memberikan segala kemudahan bagi pergaulan dengan orang lain, dimana segala keinginan tercapai dari orang tanpa susah payah adalah termasuk hal-hal yang dianggap tidak baik. Sebab pola asuhan seperti ini dapat merusakkan budi pekertinya.

Pendidikan anak sebagai satu seni menjaga dan merawat serta sebuah proses

10 Mohammad Irsyad, "Pendidikan Anak Usia Dini Menurut Imam Al Ghazali," Jurnal Edukasi AUD 2, no. 1 (9 Agustus 2017): 1-16, https://doi.org/10.18592/jea.v1i1.1533. 


\begin{tabular}{|l|l|r|}
\hline A1 Fitrah & $\begin{array}{r}\text { Mendidik Anak Usia Dini Dengan } \\
\text { Journal Of Early Childhood Islamic Education }\end{array}$ \\
ISSN $:$ 2599-2287 E-ISSN $:$ 2622-335X & Alandaskan Pemikiran Tokoh Islam \\
Vol.2 No.2 Januari 2019 & Miya Rahmawati \\
\hline
\end{tabular}

penyediaan dorongan yang membawa kepada pertumbuhan dan perkembangan yang positif.

Dan sebagai periode dasar, keberhasilan pendidikan masa awal ini akan membuat tahap-tahap berikutnya menjadi lebih mudah. Manakala tahap ini gagal, dan anak tumbuh tidak terarah dan tidak mengenal disiplin, tugas pendidikan menjadi lebih sulit, sebab ini akan melibatkan proses pelurusan arah dan penyediaan dorongan-dorongan ke arah yang diinginkannya. ${ }^{11}$

\section{b. Seimbangkan antara perintah dengan}

\section{keteladanan.}

Al Ghazali mengatakan bahwa pendidikan agama harus dimulai sejak usia dini, sebab anak-anak dalam usia ini siap untuk menerima akidah agama melalui keimanannya kepadanya, ia tidak menuntut dalil untuk menguatkannya. Oleh karena itu, dalam mengajarkan agama kepadanya, guru harus mulai pertama kali dengan memintanya menghafal kaidah-kaidah dan dasar-dasar agama, setelah itu baru guru menjelaskan pengertiannya agar dapat dipahami, diyakini dan dibenarkannya. Dengan kata lain, bahwa penanaman agama di dalam jiwa anak kecil harus dimulai dengan instruksi (perintah) dan peniruan (keteladanan). $\mathrm{Al}$ Ghazali mengatakan bahwa, agama selayaknya disajikan kepada anak pada masa awal

${ }^{11}$ Hasan Asari, Nukilan Pemikiran Islam Klasik, (Yogyakarta: PT. Tiara Wacana Yogya, 1999), hlm. 85 pertumbuhannya agar dihafalkan dengan baik. Kemudian setelah ia dewasa, maka pengertiannya akan dapat ia ketahui sedikit demi sedikit. $^{12}$

c. Gunakan metode pengajaran yang sesuai dengan minat dan bakatnya (kecerdasan jamak)

Al Ghazali menasehatkan agar guru mencari metode pendidikan yang sesuai dengan usia, minat, dan bakat anak. Guru harus kreatif mempelajari dan mencari cara mana yang bisa diterima atau ditolak murid sesuai dengan bentuk kepribadiannya. ${ }^{13}$

\section{d. Berikan waktu anak untuk bermain}

Al Ghazali juga mengingatkan baik kepada orang tua maupun kepada guru akan perlunya permainan bagi anak-anak. Ia jelaskan nilai permainan sebagai alat yang membantu pendidikan dan pengajaran anak, sebagai sarana mengungkapkan bakat dan cara yang aman untuk menghilangkan keletihan anak yang menumpuk ketika belajar. $^{14}$

Permainan mempunyai tiga tugas pokok, yang sangat dibutuhkan baik untuk pertumbuhan jasmani maupun intelektualnya. Pertama, permainan membantu untuk

$$
\begin{array}{r}
{ }^{12} \text { Fathiyah Hasan Sulaiman, Aliran-aliran } \\
\text { dalam Pendidikan Islam (Semarang: Dina Utama } \\
\text { Semarang, 1993), hlm. 47-48 } \\
{ }^{13} \text { Fathiyah Hasan Sulaiman, Konsep } \\
\text { Pendidikan al Ghazali, (Jakarta: Perhimpunan } \\
\text { Pengembangan Pesantren dan Masyarakat, 1986), } \\
\text { hlm. } 75 \\
{ }^{14} \text { Ibid..,85 }
\end{array}
$$




\begin{tabular}{|l|l|r|}
\hline & Al Fitrah & Mendidik Anak Usia Dini Dengan \\
Journal Of Early Childhood Islamic Education & Berlandaskan Pemikiran Tokoh Islam \\
Il-Ghazali \\
ISSN : 2599-2287 E-ISSN : 2622-335X \\
Vol.2 No.2 Januari 2019
\end{tabular}

menggerakkan tubuh anak serta menguatkan otot-ototnya yang akan membawa pertumbuhan jasmaninya tumbuh dengan sehat. Kedua, permainan membuat hati anak senang dan segar yang merupakan pendorong kebahagiaan yang sangat dibutuhkan. Ketiga, permainan sebagai usaha menghilangkan keletihan belajar yang dilakukan anak dengan riang merupakan salah satu hal yang mempermudah pendidikan. ${ }^{15}$

\section{e. Berikan kegiatan positif di waktu luangnya}

Menurut Al Ghazali, diantara cara-cara yang dapat digunakan untuk menjauhkan anak-anak dari pekerjaan-pekerjaan yang tak bermakna adalah membiasakannya banyak membaca khususnya membaca Al Qur`an, hadits, berbagai berita, hikayah atau cerita orang-orang yang baik serta keadaan mereka (seperti kisah-kisah nabi) agar tertanam rasa cinta kepada orang-orang baik di dalam hatinya.

\section{f. Reward and Punishment.}

Al Ghazali memandang wajib tentang masalah penghargaan dan pujian kepada anak bila ia melakukan perbuatanperbuatan yang baik atau berperilaku dengan penuh etika. Anak harus juga diberi imbalan yang baik sedapat mungkin atas segala kebaikan yang dilakukannya, bila perlu pujilah anak dihadapan orang-orang penting dan berkedudukan tinggi guna memberikan semangat kepadanya. Sebaliknya, bila anak melakukan perbuatan yang tidak terpuji, terutama jika tampak ia merasa malu dan berupaya menutupinya, sebaiknya kita berpura-pura seakan tidak mengetahuinya.

Maksudnya adalah ketika pada kesempatan pertama anak melakukan kesalahan, kita tidak langsung menegurnya, tapi memberikan kesempatan kepada anak untuk menyadari kesalahannya itu terlebih dahulu. Apabila seorang anak terbiasa melakukan kesalahan-kesalahan dalam etika, sebaiknya diratapi/dicari solusinya secara tertutup/dibicarakan dalam lingkup keluarga saja dan diperingatkan agar ia tidak mengulangi lagi kesalahan seperti itu dengan ancaman bahwa jika ia lakukan juga maka persoalannya akan dibeberkan di depan banyak orang. Al Ghazali juga menasehatkan agar pendidik tidak memberikan sanksi dan celaan secara berkepanjangan, karena hal ini akan membuatnya terbiasa dipersalahkan atas kesalahannya. Akibatnya perkataan dan nasehat menjadi tidak efektif lagi terhadap jiwanya $^{16}$

\section{Aspek-Aspek Pendidikan Anak}

Al-Ghazali mempunyai pemikiran dan pandangan yang luas mengenai aspek-aspek pendidikan yaitu bukan hanya terfokus pada aspek pendidikan akhlak saja tapi juga aspek

\footnotetext{
${ }^{15}$ Ibid..,89
} 


\begin{tabular}{|l|l|r|}
\hline A1 Fitrah & $\begin{array}{r}\text { Mendidik Anak Usia Dini Dengan } \\
\text { Journal Of Early Childhood Islamic Education }\end{array}$ \\
ISSN $:$ 2599-2287 E-ISSN $:$ 2622-335X & Alandaskan Pemikiran Tokoh Islam \\
Vol.2 No.2 Januari 2019 & Miya Rahmawati \\
\hline
\end{tabular}

yang lain seperti pendidikan keimanan, sosial, jasmaniyah dan sebagainya. Adapun aspekaspek pendidikan anak dapat kita pahami jika kita mengkaji pemikiran Al-Ghazali tentang metode melatih, mendidik, dan memperbaiki akhlak anak-anak pada awal pertumbuhan. Aspek-Aspek pendidikan anak tersebut antara lain :

\section{* Pendidikan Keimanan}

Sebelum kita menjelaskan konsep pendidikan keimanan bagi anak-anak, kita perlu mengetahui konsep iman menurut $\mathrm{Al}$ Ghazali yakni iman adalah mengucapkan dengan lidah, membenarkan dengan hati dan melaksanakan dengan anggota badan. Adapun tentang pendidikan keimanan bagi anak, Al-Ghazali berkata bahwa apa yang kami sebutkan tentang keimanan hendaknya didahulukan pada anak kecil pada awal pertumbuhannya agar dihafalkan, selanjutnya pengertiannya akan diketahui sedikit- demi sedikit. Jadi pendidikan keimanan terutama tentang ketauhidan perlu diprioritaskan pada anak kecil agar meresap dalam jiwanya. Sehingga keimanannya kelak kuat dan kokoh serta tidak mudah tergoyahkan. Karena itu dalam Islam terdapat perintah untuk mengiqomah-i dan meng-adzan-i bayi yang baru lahir selain agar kalimat yang ia dengar pertama kali adalah Asy-Syahadataini juga agar suara pertama yang didengar adalah nama Allah dan Muhammad SAW. ${ }^{17}$

\section{Pendidikan Akhlak}

Akhlak menurut Al-Ghazali adalah ibarat dari Akhlak adalah statu sikap yang mengakar dalam jiwa yang darinya lahir berbagai perbuatan dengan mudah dan gampang, tanpa perlu pemikiran dan pertologan. Jika sikap itu darinya lahir perbuatan yang baik dan terpuji, baik dari segi akal maupun sifat atau keadaan yang meresap dalam jiwa manusia yang muncul dari perbuatan-perbuatan dengan mudah tanpa membutuhkan pada pemikiran dan pertimbangan, jika sifat mampu melahirkan perbuatan yang terpuji menurut akal dan syara' maka ia dinamakan akhlak yang baik tapi jika yang muncul adalah perbuatan yang tercela maka dinamakan akhlak yang buruk. ${ }^{18}$

Tujuan dari pendidikan menurut AlGhazali adalah adanya pembentukan akhlak yang baik. Al-Ghazali menginginkan kemuliaan jiwa, keluhuran akhlak sebagai manifestasi dari proses pendidikan karena akhlak merupakan aspek fundamental dalam kehidupan seseorang, masyarakat maupun suatu negara. Akhlak juga merupakan amal yang menjadi buah dari ilmu. Amal dan ilmu

${ }^{17}$ Ibid.,hlm.144

${ }^{18}$ M. Miftahul Ulum, "Konsep Pendidikan Anak Menurut Al-Ghazali Dan Relevansinya Dengan Arah Dan Tujuan Pendikan Nasional Di Indonesia," At-Ta'dib 4, no. 2 (1 September 2009), https://doi.org/10.21111/at-tadib.v4i2.592.hlm.239 


\begin{tabular}{|l|l|r|}
\hline & Al Fitrah & Mendidik Anak Usia Dini Dengan \\
Journal Of Early Childhood Islamic Education & Berlandaskan Pemikiran Tokoh Islam \\
Il-Ghazali \\
ISSN : 2599-2287 E-ISSN : 2622-335X \\
Vol.2 No.2 Januari 2019
\end{tabular}

ibarat dua sisi mata uang yang tidak bisa dipisahkan, harus seimbang dan saling melengkapi karena ilmu tanpa amal adalah percuma sedangkan amal tanpa ilmu adalah sia-sia. ${ }^{19}$

\section{* Pendidikan Sosial}

Konsep pendidikan social bagi anak difahami dari perkataan Al-Ghazali sebagaimana berikut ini : Dan hendaklah membiasakan anak untuk tidak berbicara kecuali berupa jawaban dan sesuai dengan pertanyaannya, dan biasakanlah anak untuk mendengarkan dengan baik ketika orang lain yang lebih tua berbicara padanya. Indikator dari pernyataan Al-Ghazali tersebut menunjukkan bahwa penting sekali membiasakan anak untuk dapat bersosialisasi dengan lingkungannya dengan menjaga kesopanan dalam bergaul agar nantinya anak tersebut dapat diterima dengan baik oleh lingkungannya.

\section{* Pendidikan Jasmani}

Menurut Al-Ghazali masa awal pertumbuhan anak merupakan masa dimana anak perlu untuk melatih fungsi organ tubuhnya, memperkuat otot dan tulang serta menjaga kesehatan dan kebugaran badannya. Karena hal tersebut berfungsi sebagai penunjang dalam proses pendidikannya.

\section{Implikasi konsep pendidikan anak dalam} perspektif Al-Ghazali

\footnotetext{
${ }^{19}$ Sitti Riadil Janna, op. cit.,hlm.50
}

Implikasi konsep pendidikan anak dalam perspektif Al-Ghazali, adalah sebagai berikut

1. Pendidik

- Di hadapan muridnya, guru harus memberikan contoh yang baik, seperti berjiwa halus, lapang dada,sabra, penyayang, murah hati dan berakhlak terpuji lainnya.

- Harus memiliki pengetahuan yang baik agar mampu merumuskan metode dan materi yang bervariasi dan menyenagkan bagi anak. pendidik harus mengajarkan pelajaran yang sesuai dengan intelektual dan daya tangkap anak didiknya.

- Pendidik hendaknya mengupayakan perkembangan seluruh potensi peserta didik, baik potensi jasmani (psikomotorik) dan rohani (afektif dan kognitif) agar mencapai tingkat kedewasaan. Pengembangan potensipotensi tersebut haruslah seimbang karena peserta didik merupakan satu kesatuan jiwa-raga (cipta, rasa dan karsa) dan dilahirkan dengan berbagai potensi yang perlu untuk ditumbuhkembangkan sehingga dapat membentuk kepribadian yang utuh dan seimbang. ${ }^{20}$

${ }^{20}$ ALWIZAR, "Pemikiran Pendidikan AlGhazali", POTENSIA Jurnal Kependidikan Islam," diakses 23 Maret 2019, http://ejournal.uin- 


\begin{tabular}{|l|l|r|}
\hline A1 Fitrah & $\begin{array}{r}\text { Mendidik Anak Usia Dini Dengan } \\
\text { Journal Of Early Childhood Islamic Education }\end{array}$ \\
ISSN $:$ 2599-2287 E-ISSN $:$ 2622-335X & Alandaskan Pemikiran Tokoh Islam \\
Vol.2 No.2 Januari 2019 & Miya Rahmawati \\
\hline
\end{tabular}

2. Peserta didik.

- Peserta didik bukan merupakan miniatur orang dewasa. Ia memiliki dunianya sendiri. Pendidik harus memahami hal ini agar dalam proses pembelajaran (baik dalam metode pembelajaran dan materi yang diajarkan, sumber belajar maupun media pembelajaran), mereka tidak diperlakukan seperti orang dewasa.

- Peserta didik adalah manusia yang senantiasa tumbuh dan berkembang secara periodik. Hal ini penting untuk difahami oleh pendidik agar proses pendidikan disesuaikan dengan tingkat pertumbuhan dan perkembangan yang pada masingmasing usia anak.

\section{PENUTUP}

Konsep Pendidikan anak yang diusung oleh Al-Ghazali berpijak pada Al-Qur'an dan As-Sunnah sebagai dasar pendidikan anak. Dalam pandangan Al-Ghazali anak memiliki fitrah yang kecenderungannya ke arah baik dan buruk. Sehingga peran lingkungan dalam hal ini pendidikan dari kedua orang tua sangat dibutuhkan dalam pendidikan anak. Hal ni dapat terlihat dari pemikirannya tentang tujuan pendidikan anak yaitu tercapainya kebahagiaan akhirat yang bermuara pada

suska.ac.id/index.php/potensia/article/view/1245.hl kedekatan dengan Allah yakni hasil budi pekerti yang luhur namun tidak melupakan kebahagiaan dunia yang bermuara pada pengembangan potensi anak meliputi potensi jasmani dan rohani ('aqliyah, moral, spiritual dan sosial). Pendidikan yang dirumuskan AlGhazali mencakup banyak aspek yaitu pendidikan keimanan, pendidikan akhlak, pendidikan 'aqliyah, pendidikan sosial dan pendidikan jasmani. Mengenai metode AlGhazali menganjurkan penggunaan metode yang bervariasi yang harus disesuaikan dengan tahap perkembangan akal fikiran anak. Seperti hafalan, pemahaman, pembiasaan, latihan dan lain sebagainya.

Implikasi dari hasil pemikiran sosok ALGhazali terhadap pendidikan bahwasanya dalam mendidik anak hendaknya pendidikan selalu disesuaikan dengan tahap-tahap perkembangan peserta didik seperti perkembangan kognitif dan moralnya. Karena pendidikan merupakan proses yang sinergis antara pendidik, peserta didik, metode dan materi. Karena tugas pendidik adalah membantu peserta didik mengembangkan seluruh potensi yang ia miliki hingga mencapai kedewasaan dan peserta didik adalah sebagai pihak yang potensinya perlu dikembangakan maka segala sesuatu yang akan dirumuskan oleh pendidik baik metode maupun materi haruslah mengacu pada peserta didik yaitu pada aspek 


\begin{tabular}{|l|l|r|}
\hline & Al Fitrah & Mendidik Anak Usia Dini Dengan \\
Journal Of Early Childhood Islamic Education & Berlandaskan Pemikiran Tokoh Islam \\
Il-Ghazali \\
ISSN : 2599-2287 E-ISSN : 2622-335X \\
Vol.2 No.2 Januari 2019
\end{tabular}

perkembangannya yang selalu berdasarkan pada pembentukan akhlak.

\section{DAFTAR PUSTAKA}

Al Ghazali, Ihya' Ulumuddin, Jilid II, Alih bahasa $H$. Ismail Jakub, Jakarta: CV. Faizan, tth

Alwizar, "Pemikiran Pendidikan AlGhazali". Potensia: Jurnal Kependidikan Islam." Diakses 23 Maret 2019. http://ejournal.uinsuska.ac.id/index.php/potensia/article/v iew/1245.

Ghazali, M. Bahri. 1991. Konsep ilmu menurut Al-Ghazali, Yogyakarta:Pedoman Ilmu Jaya

Irsyad, Mohammad. "Pendidikan Anak Usia Dini Menurut Imam Al Ghazali." Jurnal Edukasi AUD 2, no. 1 (9 Agustus 2017): 1-16. https://doi.org/10.18592/jea.v1i1.1533.

Janna, Sitti Riadil. "Konsep Pendidikan Anak Dalam Perspektif Al-Ghazali (Implikasinya dalam Pendidikan Agama Islam)." Al-Ta'dib 6, no. 2 (1 Juni 2013): 41-55. https://doi.org/10.31332/atdb.v6i2.304.

Kurnanto, Muhammad Edi. "Pendidikan Dalam Pemikiran Al-Ghazali." Khatulistiwa 1, no. 2 (1 September 2011).

https://doi.org/10.24260/khatulistiwa.v $1 \mathrm{i} 2.189$.

Nurcholish, Madjid. 1998.Islam Kemodernan dan Keindonesiaan, Bandung : Mizan,

Sa'adah, Nurus. "Konsep pendidikan anak dalam perspektif Al-Ghazali: Analisis teori tahap-tahap perkembangan jean piaget." Undergraduate, Universitas Islam Negeri Maulana Malik Ibrahim, 2008. http://etheses.uinmalang.ac.id/4282/.
Sulaiman, Fathiyah Hasan, 1993. AliranAliran dalam Pendidikan Islam, Semarang: Dina Utama Semarang.

Sulaiman, Fathiyah Hasan, 1986. Konsep Pendidikan Al Ghazali, Jakarta: Perhimpunan Pengembangan Pesantren dan Masyarakat.

Ulum, M. Miftahul. "Konsep Pendidikan Anak Menurut Al-Ghazali Dan Relevansinya Dengan Arah Dan Tujuan Pendikan Nasional Di Indonesia." At-Ta'dib 4, no. 2 (1 September 2009). https://doi.org/10.21111/attadib.v4i2.592.

Zar, Sirajuddin. 2012.Filsafat Islam:Filosof Dan Filsafatnya. Depok : Rajagrafindo Persada 